\title{
IDB lending to budget oversight institutions
}

\author{
Carlos Santiso
}

I

ernational financial institutions are showing a renewed interest in measures to enhance national budget management and strengthen the integrity of public finance in emerging economies. The role of national parliaments and supreme audit institutions in the governance of the budget and the accountability of public finances is being rediscovered. To strengthen the contribution these institutions make to the budget process, the Inter-American Development Bank (IDB) is providing them with multilateral loans whose potential remains unexplored and whose effectiveness could be improved. Besides increasing technical capacity and enhancing operational efficiency, second-stage reforms should enhance the governance of public finance and fiscal control by ensuring greater financial autonomy and political independence for supreme audit institutions and promoting more efficacious links between supreme audit institutions and parliamentary public accounts committees.
Carlos Santiso

Political economist,

School of Advanced International Studies, Johns Hopkins University,

Washington, D.C.

• csantiso@jhu.edu 


\section{Exploring uncharted territory}

It is increasingly recognized that the quality of the budget process is a critical determinant of good government. Budget transparency and fiscal oversight are critical for enhancing public finance management, ensuring government accountability and curbing corruption. Consequently, the governance of the budget and the institutions of accountability, transparency and integrity in public finance are the subject of renewed scrutiny.

In the course of the 1990s, there was a general move towards a second wave of reform strategies to enhance public budgeting and public finance management in emerging economies. Traditional approaches have tended to focus on improving efficiency and effectiveness within the executive branch, in particular finance ministries, executing agencies, tax authorities and central banks. In recent years, however, greater attention has been directed at strengthening the institutions of economic governance beyond the executive branch and improving the mechanisms of oversight and accountability. This second stage of reform is partly the result of new findings on the determinants of the quality of economic policy and the need to balance executive discretion in public budgeting with mechanisms ensuring government accountability. This has led to a renewed interest in the credibility of public finance systems and the contribution of national parliaments

$\square$ The author specializes in the political economy of governance reform and public finance accountability in emerging markets, in particular public budgeting and external auditing. This essay was partly drafted during his tenure as a Visiting Fellow at the Anticorruption Office of the Ministry of Justice, Security and Human Rights of Argentina in July-August 2003. Opinions expressed herein are those of the author only and should not be taken as reflecting those of the aforementioned institutions. The author is grateful to Linn Hammergren, Javier Santiso, Lynette Asselin, María Isabel dos Santos, Joachim Wehner, Warren Krafchik, John Williamson, Enrique Paixão, Alfredo Fólica, Arturo Aylwin, Julio Rodolfo Comadira, Miriam Ivanega, Delia Ferreira Rubio, Néstor Baragli, Manuel Garrido, Patricia Llanos, Hernán Llanos, Simon Gill, Yasuhiko Matsuda and an anonymous reviewer for their encouragement, comments and suggestions.

${ }^{1}$ Supreme audit institutions are also referred to as general accounting offices or national audit offices. The term "supreme audit institution" will be used hereafter to refer to those institutions tasked with the external audit of government programmes and public accounts. and supreme audit institutions ${ }^{1}$ to budget accountability. $^{2}$

The introduction of governance concerns in the development agenda has led international financial institutions (IFIs) to broaden the scope of their efforts to promote economic reform and governmental financial management. These IFIs provide significant support to strengthen the institutions of public finance governance in emerging economies in the broader context of the second-generation institutional reforms being sought (Santiso, 2004c and 2003a; Burki, Perry and others, 1998). A salient feature of new approaches to public-sector reform is the narrowing of the gap between the economic and political aspects of governance, a trend that is particularly noticeable in the IDB approach.

The IFIs have a fiduciary and a developmental interest in improving accountability in public finance management. Mitigating fiduciary risk in policy-based lending and direct budget support necessarily requires strong, credible and reliable budget management systems in recipient countries (Santiso, n/d).

The World Bank adopted a strategy to guide its involvement in governance issues in November 2000 (World Bank, 1997 and 2000) and the idb updated its strategy for the modernization of the State in July 2003 (IDB, 2003). These strategies underscore the contribution of parliaments and supreme audit institutions to government accountability in public finance management. Furthermore, prompted by recent findings on aid effectiveness, State capture and corruption, the IFIs have upgraded their diagnosis instruments for evaluating the quality of public budgeting and the robustness of the mechanisms of accountability in government finances. ${ }^{3}$ For example, the Public Expenditure and Financial Accountability (PEFA) programme, a multi-donor initiative established in December 2001, aims at harmonizing international public-sector standards in accounting, auditing and

\footnotetext{
2 See Santiso (n/d, 2004a and 2004b), Haggard and McCubbins (2001), Schedler, Diamond and Plattner (1999) and Mainwaring and Welna (2003).

${ }^{3}$ See DFID (2001 and 2002), Brobäck and Sjölander (2002) and PEFA (2003).
} 
internal control in developing and transitional countries. ${ }^{4}$ The bilateral aid agencies assembled in the Utstein group (Germany, the Netherlands, Norway and the United Kingdom) have been particularly active in supporting government accountability institutions in developing countries. ${ }^{5}$

Similarly, in the context of European Union (EU) enlargement, the European Court of Auditors (ECA) has been particularly active since 1993 in building the institutional capacity of supreme audit institutions in candidate countries from Central and Eastern Europe, as part of the process of convergence towards EU standards of public finance management and auditing. ${ }^{6}$ The Support for Improvement in Governance and Management in Central and Eastern European Countries (SIGMA) programme, established in 1992 as a joint initiative of the then European Community (EC) and the Organisation for Economic Co-operation and Development (OECD), has contributed to the modernization of supreme audit institutions and the strengthening of external control mechanisms in the public sector of candidate countries. Accession has provided a unique incentive to strengthen public finance accountability systems in those countries set to join the EU. For instance, the process established to monitor implementation of the 1997 Copenhagen criteria has allowed reforms to gradually expand and consolidate, leading to the accession of a first wave of 10 countries in May 2004.

In the case of Latin America and the Caribbean, the institutional strengthening of finance ministries and tax agencies has been supported by the multilateral development banks and the United States Government, acting through its General Accounting Office (USGAO) and the United States Agency for International Development (USAID). Already in the 1920s and 1930s, the United States provided technical assistance to Latin American countries for establishing their central banks and upgrading their systems of government finance (Drake, 1989). The Kemmerer missions to the Andean countries helped set up strong comptroller- and auditor-

\footnotetext{
${ }^{4}$ See www.pefa.org

${ }^{5}$ See, in particular, the Utstein Anti-Corruption Centre, www.u4.no. For more information on donor-funded projects, see also www.respondanet.com.

${ }^{6}$ Paradoxically, the ECA has not been able to certify the accounts of the EU in the past eight years, reflecting the difficulty of redressing structural dysfunctions in financial management systems.
}

general's offices to provide for central accounting and auditing of government finances. Similarly, since the early 1990s the World Bank, IDB and USAID have helped Latin American countries to modernize their financial administration through the establishment of integrated financial management systems (Dorotinsky and Matsuda, 2002). In the course of that decade, Argentina, Bolivia, El Salvador, Guatemala, Honduras, Nicaragua and Venezuela benefited from technical assistance loans and grants to enhance their governmental financial management systems.

This essay reviews IDB lending to the institutions of budget oversight and public finance accountability in Latin America and the Caribbean, essentially national parliaments and supreme audit institutions. The support given by the IDB to legislative budget institutions and external audit agencies is part of its broader effort to enhance financial management in the public sector of borrowing countries. Nevertheless, this essay argues that the second stage of economic reform requires new approaches to strengthen the institutions of public finance governance (Krueger, 2000). It involves addressing the political economy determinants of governance reform and fiscal control. In particular, ensuring greater oversight and integrity in public finance necessarily requires enhancing the functional linkages between the different institutions participating in the budget process and the national system of control.

The essay is divided into four sections. Section II that follows briefly reviews the new approach being taken by the IFIs to public finance management, which underscores concerns over transparency and accountability. Section III focuses on the patterns of IDB concessional lending to supreme audit institutions and parliaments in Latin America and the Caribbean. It is argued that there exists unexplored potential to enhance the effectiveness of supreme audit institutions and national parliaments in public budgeting, which would entail addressing the political economy of institutional reform and fiscal control. Besides increasing technical capacity and enhancing operational efficiency, second-stage reforms need to strengthen the political independence and financial autonomy of supreme audit institutions and promote more efficacious links between these institutions and parliamentary public accounts committees. Section IV, lastly, offers some observations on the political aspects of public finance accountability. 


\section{II}

\section{Rethinking public finance accountability}

The agencies of public finance accountability constitute a critical component of the new paradigm of development economics. They are key determinants of the institutional capabilities required to undertake second-generation economic reforms beyond the Washington consensus (Krueger, 2000; Kuczynski and Williamson, 2003; Santiso, 2004c and 2003a). In the first stage of reform, the policy prescriptions of the Washington consensus favoured a predominant role for the executive in public budgeting and the insulation of economic policy-making. However, abuses by strong presidents misusing the prerogatives of executive decree authority and the delegation of legislative authority have often led to the neutralization of accountability mechanisms, the capture of supreme audit institutions and restrictions on the role of parliaments in the budget process (Santiso, 2001a and 2001b). Accordingly, the second-generation reforms now being encouraged seek to restore the mechanisms of transparency, oversight and accountability in the governance of the budget.

\section{Governance and public finance}

The quality of a country's governance system is a key determinant of the ability to pursue sustainable economic and social development. The push by IFIs to confront governance challenges in developing countries has largely originated in the urgent need to tackle the structural causes of embedded corruption. This scourge became a core concern of the World Bank in 1996 when its new president, James Wolfensohn, committed the organization to fighting the "cancer of corruption". It is now well established that corruption has corrosive effects on both economic management and aid effectiveness. Thenceforth, the World Bank began supporting programmes to strengthen accountability institutions, such as the rule of law, judicial systems, public finance management systems, and parliamentary oversight mechanisms (World Bank, 2000). In 1997, it adopted an anti-corruption strategy aimed at mainstreaming anti-corruption in its lending policies and practices.

According to the standard World Bank definition, the concept of governance captures "the manner in which power is exercised in the management of a country's economic and social resources for development" (World Bank, 1992, p.1). It encompasses the form of the political regime, the process by which authority is exercised in the management of a country's economic and social resources for development, and the capacity of governments to design, formulate and implement policies and discharge functions. Yet, the "importance of government credibility and commitment to policy reform has been essentially neglected as a pivotal condition for effective economic reform" (Ahrens, 2001, p. 75). Credibility in economic policy largely depends on the effectiveness of the mechanisms of accountability (Haggard and McCubbins, 2001; Santiso, 2004a).

\section{Approaches to governance reform}

Governance is a difficult concept for the multilateral development banks, which do not want to be seen as political and thus adopt a doctrine of political neutrality (Santiso, 2001c and 2004d). One of the most contentious issues relates to the distinction between economic and political aspects of governance. While the World Bank recognizes that governance is intrinsically a political concept, it is careful to stress that its engagement through lending, technical assistance and policy advice is confined to its economic dimensions, and notes that the nature of the political system falls outside the purview of its mandate as enshrined in its Articles of Agreement. Similarly, the Asian Development Bank (ASDB), which was the first regional bank to adopt a governance policy in 1995, defines good governance as "sound development management" based on four interrelated "pillars": accountability, transparency, predictability and participation. For AsDB, "good governance is good government" (AsDB, 1995 and 1999). The African Development Bank (AFDB) follows a similar approach (AfDB, 2000).

The IDB approach to State reform and publicsector modernization shares several features with that of the World Bank, in particular its technical bias (Santiso, 2000). In theory, and like the European Bank for Reconstruction and Development (EBRD, 1992), the IDB adopts a more explicitly political approach to governance reform. It is generally less reluctant to engage in politically sensitive areas and confront the political economy of institutional development. It had 
broader political goals enshrined in the expansion of its mandate in 1994, so that this now includes the consolidation of democracy as one of its corporate objectives. The IDB policy on the modernization of the State was first articulated in 1996. It was updated in 2003 to integrate concerns over the political economy of reform, in particular party systems, electoral rules and executive-legislative relations (IDB, 2003). The Bank authorities recognize that politics matters for development and that, consequently, lending and technical assistance should more actively address political economy considerations (Payne, Zovatto and others, 2002).

Undeniably, the introduction of the governance agenda has led the IFIs to broaden the scope of their interventions, entering largely uncharted territories such as judicial reform, parliamentary strengthening and anti-corruption. Between 1996 and 2000, the World Bank began over 600 governance-related programmes and initiatives in 95 countries, and between 1987 and 1998, it carried out 169 civil service reform programmes in 80 countries. In Latin America, according to recent estimates, it undertook 126 core public-sector reform projects between 1982 and 2002, totalling US\$ 12 billion (Fuhr and Krause, 2003). A majority of these projects, usually policy-based loans with a marked emphasis on fiscal reform, have a strong focus on public budgeting and government financial management. Similarly, legal and judicial reform has become a core component of the World Bank governance portfolio (Santiso, 2004d). Since 1991, the World Bank has financed 480 projects in 84 countries that deal with or include components of legal and judicial reform, totalling US\$380 million. Between 1991 and 2001, the Bank approved 35 projects exclusively devoted to judicial reform. ${ }^{7}$ It has also established targeted lending instruments and upgraded its own capacities to assess judicial performance and promote judicial reform by undertaking judicial sector assessments (JSAs) since 1994 and more comprehensive institutional and governance reviews (IGRs) since 1999.

Similarly, between 1993 and 2001, the IDB approved 18 loans and 65 technical co-operation operations to reform judicial systems and modernize the administration of justice in 21 of its 26 member

\footnotetext{
7 The Bank's Legal Vice Presidency has provided legal advice to over 87 countries in over 45 specialized areas since 1986, and training in legal and judicial reform has also become a core activity of the World Bank Institute (WBI).
}

countries, amounting to US\$ 461 million in investment (Biebesheimer and Payne, 2001; Santiso, 2003b).

The International Monetary Fund (IMF) was also urged in 1996 by its Board of Governors to "promote good governance in all its aspects, including by ensuring the rule of law, improving efficiency and accountability in the public sector, and tackling corruption, as essential elements of a framework within which economies can prosper". Since then, the Fund's role in governance has expanded considerably, integrating concerns over transparency, accountability and predictability of fiscal policy (IMF, 1997 and 2001). The Fund has spread the neutral mantle of technical expertise over its approach to governance reform, focusing on those economic aspects of governance that could have a significant macroeconomic impact and those that affect the implementation of economic reforms. In 1997, it adopted guidelines specifying that its "involvement in good governance should be limited to economic aspects of governance" (IMF, 1997, p. 3), namely, the transparency of government accounts, the effectiveness of public resource management, and the stability of the regulatory environment for privatesector activity. Nevertheless, the Fund's position regarding the political context of borrowing countries remains ambiguous, as its involvement in Indonesia and Argentina reflects.

The Fund's involvement in the reform of domestic governance stems in part from its new role in capitalaccount management and its promotion of structural adjustment since the 1980 s. These new roles necessarily entail a more continuous involvement in the reform of borrowing countries' policies beyond temporary crisis management. The main channels through which the Fund promotes good governance are surveillance, lending and technical assistance. In terms of surveillance, the Fund has actively sought to promote standards and codes of good practice through consultations under Article IV of its Articles of Agreement, particularly with regard to fiscal matters.

Since the late 1990s, the Fund has acknowledged the importance of transparency in monetary and financial policy management, adopting a Code of Good Practices on Fiscal Transparency in $2001 .^{8}$ A country's observance of these standards is assessed in the Reports

\footnotetext{
${ }^{8}$ The Fund has identified 12 key areas, which include accounting, auditing, anti-corruption, banking supervision, corporate governance, fiscal transparency, monetary policy and financial policy transparency.
} 
on the Observance of Standards and Codes (ROSCs); 264 of these had been completed for 80 countries by the end of June 2002, of which 193 have been published. These diagnosis instruments complement those used by the World Bank to assess the quality of public finance processes, such as Public Expenditure Reviews (PERs) and Country Financial Accountability Assessments (CFAAs). Although they possess different mandates and perform different functions, the IFIs are seeking to better coordinate and harmonize their assessment instruments over the public finance cycle, from revenue collection to expenditure management (PEFA, 2003).

\section{Budget oversight}

The role of parliaments and external auditing agencies in public budgeting, public finance accountability and corruption control figures prominently in the new strategy on the modernization of the State adopted by the IDB in July 2003. ${ }^{9}$ After a first wave of reforms targeting the efficiency and effectiveness of government financial management systems within the executive, the new strategy acknowledges the critical importance of the mechanisms of transparency and external oversight in the budget process. The role of national parliaments in public budgeting is being rediscovered throughout the region.

In its efforts to consolidate democratic governance, the IDB (2003) stresses the need to "strengthen the institutional capacity of the legislative branch", in particular by supporting programmes designed to "strengthen technical assistance systems that will improve the quality of legislation and help ensure budgetary, monitoring and oversight functions are performed based on objective and technical criteria" (p. 12). Furthermore, the strategy allows the IDB to provide support for increasing "the technical capacities and functional independence of institutions that oversee government performance, for example, the offices of the comptroller general, court of accounts, auditor general, ombudsman, public defender, public prosecutor and attorney general" (p. 13).

Accordingly, parliaments and supreme audit institutions are to be approached as key components in national systems of control. The IDB recognizes that "audit and other supervisory institutions do not always have the independence, objectivity and technical capacities necessary for them to be able to oversee adherence to the rule of law" (IDB, 2003, p. 5). It notes that "the prevalence of corruption is to some degree an expression of the weakness of the rule of law, but calls attention also to the weakness of the State's financial administration" (p. 5). The IDB approach emphasizes the need to "strengthen the fiscal capacity of the State and improve the efficiency and transparency of expenditure management" and the necessity of implementing "comprehensive financial and accounting management systems and promoting the transparency of budgetary information" (p. 18).

\section{III}

\section{Lending to budget oversight institutions}

In recent years, the IFIs have "rediscovered" public budgeting, in particular the role of parliaments and external audit agencies in the governance of the budget. Consequently, the contribution of legislative budget institutions to budget policy-making and oversight is being re-evaluated. It is being increasingly recognized that these institutions are critical to enforcing government accountability and guaranteeing integrity

\footnotetext{
${ }^{9}$ The strategy focuses on four priority areas of intervention: the democratic system; the rule of law and justice reform; State, markets and society; and public management.
}

in public finance management. In particular the importance of parliamentary budget and public accounts committees is being re-emphasized, especially in presidential systems. The OECD Best Practices for Budget Transparency (OECD, 2001a) include considerations concerning the role of parliaments in the budget process, and thus go a step further than the IMF Code of Good Practices on Fiscal Transparency, which tends to restrict itself to the governance of the budget within the executive. This restraint is also noticeable in the assistance provided by the IFIs to transitional countries reforming their budget procedures. Furthermore, technical assistance has tended to 
concentrate either on the expenditure side, providing assistance to prime minister's offices and finance ministries, or the revenue side, providing tax reform advice and strengthening the capacities of tax authorities.

Nevertheless, in recent years multilateral development banks have started to broaden their support for budget policy-making and oversight institutions, by lending support to supreme audit institutions and national parliaments. While their approach remains restrained by a technical bias which tends to inhibit them from addressing politically sensitive governance issues such as the deficient links between supreme audit institutions and parliamentary public accounts committees, this is starting to change. Indeed, the effectiveness of fiscal control mechanisms and legislative budget oversight in Latin America is hampered by the dysfunctional relations between the individual components of the systems of control and integrity in public finances. In general, these different components tend to act in isolation from one another. This has allowed corruption to flourish almost unrestricted in countries such as Argentina under Carlos Menem (1989-1999) and Peru under Alberto Fujimori (1990-2000), where the institutions of integrity and accountability were particularly vulnerable to capture.

Ultimately, as this essay argues, the effectiveness of national integrity systems largely depends on the strength of the synergies between their different components, including government accounting systems, internal auditing mechanisms, external control institutions, administrative and criminal courts, and parliamentary oversight committees (Diamond, 2002). The support provided by the IDB to national parliaments and supreme audit institutions will now be briefly reviewed.

\section{Lending to national parliaments}

Parliamentary strengthening is a relatively new area for multilateral development banks. There is indeed heightened awareness of the role of parliaments in the budget process and their responsibility in ensuring government accountability. ${ }^{10}$ Legislatures play a pivotal role in the budget process, contributing to democratic accountability and providing the necessary "checks and balances" to executive discretion in

${ }^{10}$ See Krafchik and Wehner (1998), OECD (2001b), Manning and Stepenhurst (2002) and Wehner (2003). presidential systems. Indeed, the general trend is for legislatures to take a more active role in the budget process. However, they have to demonstrate that they are able to do so responsibly and ensure fiscal discipline. The challenge facing Latin American legislatures is to strengthen the institutional arrangements fostering fiscally responsible interventions.

In Latin America and the Caribbean, as table 1 shows, the IDB approved seven lending operations between 1994 and 2003 totalling US\$ 45 million, as part of parliamentary reform programmes totalling over US\$ 60 million. The stated aim of IDB financing is to strengthen the representative, legislative and oversight functions of parliaments. The bulk of financing is directed at "hardware investments" such as physical infrastructure development, information technology improvements, and human resources management.

A salient feature of IDB lending to this sector is its focus on enhancing the role of parliament in the budget process, primarily by improving committee work, strategic planning and capacities for legislative research. Legislatures are central both to the making of budget policy (through the budget committees approving the State budget) and to the oversight of budget execution (through the public accounts committee). A first set of initiatives supported by the IDB aims at strengthening legislatures' internal structures and the procedures shaping the legislative process. There is a marked emphasis on those parliamentary committees involved in the budget process, at either the approval or the oversight stage (e.g., the budget and public accounts committees). Public accounts committees, now regarded as a core legislative budgetary institution, are a critical linkage between the responsibility of parliament in enforcing government accountability in public finance and the external auditing function performed by supreme audit institutions (Wehner, 2002). A second set of IDB initiatives aims at enhancing the capacities of parliaments for independent budget analysis, contributing to the creation or strengthening of legislative research centres and budget offices advising budget and public accounts committees. IDB lending operations have been relatively successful in helping parliaments to enhance their research and advisory services. In Venezuela they have contributed to the creation of legislative budget offices, although this remains an isolated case.

The strengthening of legislative budgetary powers also reflects a gradual shifting of power between the executive and the legislative branches in Latin 


\begin{tabular}{|c|c|c|c|c|c|c|}
\hline \multirow{3}{*}{ Year } & \multicolumn{5}{|c|}{$\begin{array}{l}\text { Latin America: Inter-American Development Bank lending } \\
\text { to national parliaments }\end{array}$} & \multirow{3}{*}{$\begin{array}{c}\text { Disbursement } \\
\text { period } \\
\text { (years) }\end{array}$} \\
\hline & \multirow[t]{2}{*}{ Country } & \multirow[t]{2}{*}{ Title } & \multicolumn{3}{|c|}{ Amount (millions of dollars) } & \\
\hline & & & Total & $\begin{array}{l}\text { IDB } \\
\text { lending }\end{array}$ & $\begin{array}{l}\text { Counterpart } \\
\text { financing }\end{array}$ & \\
\hline 2003 & Peru & $\begin{array}{l}\text { Institutional Strengthening Programme for the } \\
\text { Peruvian Congress }\end{array}$ & 10 & 7 & 3 & 4.5 \\
\hline 2000 & Honduras & Modernization of the Honduran Congress & 3.25 & 2.60 & 0.65 & 4 \\
\hline 2000 & $\begin{array}{l}\text { Dominican } \\
\text { Republic }\end{array}$ & $\begin{array}{l}\text { Programme for Modernizing the National Congress and } \\
\text { the Office of the Comptroller-General }\end{array}$ & $\begin{array}{c}28 \\
(25.55)^{\mathrm{a}}\end{array}$ & 22.30 & 5.70 & 3 \\
\hline 1999 & Colombia & Modernization of the Congress of Colombia & 10 & 6 & 4 & $\cdots$ \\
\hline 1999 & El Salvador & $\begin{array}{l}\text { Modernization and Strengthening of the } \\
\text { Legislative Assembly }\end{array}$ & 4.40 & 3.50 & 0.90 & 4 \\
\hline 1996 & Panama & Project to Modernize the Legislature & 4.10 & 2.80 & 1.30 & 4 \\
\hline 1994 & Peru & $\begin{array}{l}\text { Institutional Development for the Legislative } \\
\text { Branch of Government }\end{array}$ & 3.74 & 2.70 & 1.04 & $\ldots$ \\
\hline Total & & & 61.04 & & & \\
\hline
\end{tabular}

Source: Based on projects approved as of October 2003, www.iadb.org.

a Amount allocated to the parliament.

American presidential systems. Legislatures are becoming increasingly assertive as opposition parties make strides. Historically, legislatures have been dominated by majorities belonging to or associated with the president's party. This is starting to change and many presidents no longer control legislative majorities. These new dynamics of executivelegislative relations are having a significant impact on economic policy-making and public budgeting. Legislatures are gradually re-asserting their powers of budget oversight, partly as a result of the new-found assertiveness of parliamentary oppositions. Divided government - the situation in which the president no longer controls the legislature - is becoming increasingly common throughout the region and creating new constraints on executive discretion in public budgeting. The surge of legislative activism in public budgeting in Mexico is partly the result of the emergence of an assertive opposition since the longtime ruling party, the Institutional Revolutionary Party, lost its majority in parliament in 1997 (Carbonell, 2002; Weldon, 2002). In Brazil, parliament has traditionally been the privileged arena for porkbarrelling over budget appropriations and amendments (Samuels, 2002). Even in Argentina, a country characterized by relatively disciplined parties, public budgeting has been the subject of more conflict and bargaining than formerly (Eaton, 2002; Jones, 2001).

The case of Mexico is illustrative. Since 1997, Mexico has undertaken a series of institutional reforms specifically aimed at strengthening the role of parliament in budget policy-making and oversight. The technical capacities for independent budget scrutiny were significantly enhanced with the establishment in 1998 of the well staffed and funded Centre for the Study of Public Finances (Centro de Estudios en Finanzas Públicas, CEFP) in the lower chamber of parliament. The Mexican parliament's general research capacities were already fairly substantial by that time, with the Research and Analysis Service (Servicio de Investigación y Análisis, SIA) of the parliamentary library and the Institute for Legislative Research of the upper chamber of parliament (Instituto de Investigaciones Legislativas del Senado de la República, IILSEN), created in 1985 to provide general technical advice to the Senate. Thus, parliament is now better equipped than before to discharge its budgetary responsibilities. It is indeed noticeable that a main impediment to legislative budgeting often resides in the incapacity of a parliament to engage with the budget process, rather than the restraints put on its budgetary powers. Technical capacities are thus important 
considerations when assessing the effective role of legislatures in budget oversight. In 1999, after four years of negotiations, an external audit office was established specifically to assist parliament in the oversight of federal public finances and the certification of public accounts. The Supreme Federal Auditing Office (Auditoría Superior de la Federación, ASF) was created as an advisory body to the lower chamber of parliament, assisting the latter in the review of budget execution and certification of the federal government public accounts. In 2000, parliament also passed a law on external oversight and accountability (Ley Superior de Fiscalización de la Federación). The emergence of an effective parliamentary opposition as a result of the 1997 elections, which ultimately succeeded in defeating the long-time ruling party in the general elections of 2000, thus significantly increased both the incentives and the capacities for effective legislative budget oversight.

The contribution of parliamentary budget offices to effective budget oversight is increasingly recognized, as it allows parliaments to access independent sources of budget analysis, rather than relying on the information provided by the government. Access to budgetary information is indeed strategic in the sense that it is the parliamentary opposition that has the greatest incentives to strengthen parliament's capacities for independent budget analysis, thereby allowing it to effectively oversee government performance (Messick, 2002; Rubio Llorente, 1993). Capable professional staff and institutionalized technical expertise within parliament itself are necessary conditions for legislatures to be able to exercise their budget oversight functions effectively and responsibly. The lack of professional legislative staff and the absence or weaknesses of advisory services to parliamentary committees are major hindrances to effective legislative budgeting. Members of parliaments, including those sitting on the budget and public accounts committees, do have their own political advisors. However, standing parliamentary committees lack the necessary research and advisory capacity and permanent advisors with the required technical expertise and institutional memory. This, too, is starting to change. Although not as powerful as the United States Congressional Budget Office (сво), incipient legislative budget offices are tending to gradually emerge throughout Latin America, reflecting an increasing recognition of the current weakness and, simultaneously, the potential contribution of parliaments to budget oversight. Chile, Mexico and Venezuela possess incipient legislative budget offices, while Argentina and Colombia are currently considering establishing such offices.

Understandably, the IDB is reluctant to engage in reform of the incentive structure shaping the role of parliaments in the budget process, in particular the quality of the legislative process, the role of political parties and parliamentary groups, executive-legislative relations and electoral rules. These are indeed very complex and sensitive areas, which do not lend themselves to quick fixes and transposed institutional solutions. They require a solid understanding of the interests and incentives shaping the behaviour of individuals in institutional contexts. The IDB, which is owned by borrowing governments and staffed by highquality policy makers from the region, is well placed to understand these dynamics. Yet, lending operations tend to confine themselves to the inner working of parliaments, rather than approach public budgeting as an integral process. As a result, loan operations often fail to generate the systemic impact they potentially could have on the quality of the budget process and parliament's role in budget oversight.

More fundamentally, it is increasingly recognized that the nature of the political regime and the quality of the political party system are key variables. In particular, "opposition parties have the greatest incentive to oversee government" (Messick, 2002, p. 2) and ensure effective oversight of government financial management. Indeed, in many parliamentary systems, such as the United Kingdom, a representative of the main opposition party chairs public accounts committees. Ultimately, the degree of cohesion and discipline of political parties determines, to a great extent, the effectiveness of the institutions of accountability and the quality of executive-legislative relations. Understandably, these are extremely difficult questions and highly contentious areas of engagement for the IFIs.

A critical challenge for strengthening legislative budget oversight is that only the parliamentary opposition, when it exists, has an interest in enhancing parliament's capacities for effective budget oversight, and thus an incentive to create or strengthen legislative capacities for independent review. As a result, the strengthening of legislative budget institutions must necessarily be approached in the broader context of executive-legislative relations in presidential systems of government.

In Venezuela, for example, an Economic and Financial Advisory Office (Oficina de Asesoría Económico y Financiera de la Asamblea Nacional, 
OAEF) was created in 1997 within the National Assembly, with IDB support. Its objective was to enhance the technical advisory services of parliament in public finance. This new parliamentary structure was able to draw on existing sources of legislative research and analysis, such as the Autonomous Legislative Information Service (Servicio Autónomo de Información Legislativa, SAIL) created in 1994. Nevertheless, increasing tensions between the executive and the legislature since President Hugo Chávez took office have undermined the functioning of the OAEF, which was closed in February 2000 to be subsequently reopened in June of the same year, as part of the reactivation of the loan suspended by the IDB. In 20022003 it came under renewed pressure (Rojas and Zavarce, 2004). The case of Venezuela is particularly interesting because the IDB became, willingly or not, an actor in the struggle between the executive and the legislature over budgetary powers.

\section{Lending to supreme audit institutions}

Lending to supreme audit institutions is also a relatively new area for multilateral development banks (Llanos, 2002). In theory, supreme audit institutions act as a core oversight mechanism to ensure that government is held to account for the manner in which it manages public finances. They are independent State institutions responsible for auditing government performance and public accounts and, in some cases, supervising the internal auditing system. ${ }^{11}$ While significant progress has been made over recent years in improving legal and financial compliance in government spending, much remains to be done to anchor performance auditing, as well as the effective external auditing of budget execution. In many Latin American countries, external auditing of budget execution and certification of public accounts remains deficient, and external audit reports fail to inform the budget-making process in a timely manner.

The multilateral development banks have only recently begun to support auditors-general and strengthen supreme audit institutions, and their role is still modest. IDB support for supreme audit institutions

\footnotetext{
11 In some countries supreme audit institutions also act as the supervisory agency for internal government auditing. Although this essay focuses on external auditing, it is to be noted that the links (or lack thereof) between internal and external auditing functions are critical (Diamond, 2002).
}

has generated great expectations in many countries, as it is taking place at a critical stage of the reform process and the modernization of the State. As countries realize that sound public financial management and effective anti-corruption mechanisms require robust accountability institutions, especially in Latin America's presidential systems, IDB support for supreme audit institutions necessarily occurs in the broader context of the work needed to strengthen governmental financial administration. This being So, IDB lending constitutes a potent signalling mechanism that may help strength the hand of reformers. For example, in Chile, the US\$ 25 million loan programme agreed with the IDB in 2001 has allowed the Chilean supreme audit institution to pursue its institutional strengthening programme, which probably would not have been possible otherwise.

Since 1993, the IDB has approved nine institutional strengthening projects for supreme audit institutions in Latin America, involving lending of over US\$ 50 million in the context of institutional strengthening worth over US\$ 90 million, while two new operations worth over US\$ 12 million are in the pipeline. When the latter are approved, the loan portfolio will total some US\$ 65 million (table 2). While these are regarded as "pilot" loans by the IDB, since they are still considered "innovative", the pace has been quickening since 2000.

Nevertheless, the relative size (in financial terms) of these operations varies across countries, in both absolute and relative terms. Therefore, expectations about their impact ought to be realistic. Table 3 shows the contribution of IDB loans to the budget of supreme audit institutions in Brazil, Chile, Colombia and Nicaragua.

Several issues are worth underlining. First, bilateral lending represents only a portion of the institution's budget, which can nevertheless be substantial in some cases. While in Nicaragua IDB lending contributes almost $30 \%$ of the annual budget of the supreme audit institution, in Brazil the figure is barely $1 \%$. In Chile and Colombia, IDB lending represents approximately $18 \%$ and $11 \%$ of the institution's annual budget, respectively. As might be expected, this figure tends to be higher for smaller countries, since the IDB regards these projects as "innovative loans". Second, budget allocations to supreme audit institutions have tended to increase in recent years, although their share of the national budget remains small. In the case of Brazil, the budget of the Federal Court of Accounts (Tribunal de Contas da 
TABLE 2

Latin America: Inter-American Development Bank lending to supreme audit institutions

\begin{tabular}{|c|c|c|c|c|c|c|}
\hline \multirow[t]{2}{*}{ Year } & \multirow[t]{2}{*}{ Country } & \multirow[t]{2}{*}{ Title } & \multicolumn{3}{|c|}{ Amount (millions of dollars) } & \multirow{2}{*}{$\begin{array}{c}\text { Disbursement } \\
\text { period } \\
\text { (years) }\end{array}$} \\
\hline & & & Total & $\begin{array}{l}\text { IDB } \\
\text { lending }\end{array}$ & $\begin{array}{l}\text { Counterpart } \\
\text { financing }\end{array}$ & \\
\hline 2004 & Peru $^{\mathrm{a}}$ & $\begin{array}{l}\text { Modernization of the Office of the Comptroller-General } \\
\text { and deconcentration of the national oversight system }\end{array}$ & 14.50 & 10.15 & 4.35 & 4 \\
\hline 2002 & Brazil & Modernization of the Federal Court of Accounts & 10 & 5 & 5 & 3 \\
\hline 2002 & Chile & $\begin{array}{l}\text { Modernization of the Office of the Comptroller-General } \\
\text { of the Republic }\end{array}$ & 25 & 15 & 10 & 4.50 \\
\hline 2002 & Nicaragua & Modernization Programme of the General Auditing Office & 6 & 5.40 & 0.60 & 4 \\
\hline 2000 & Colombia & $\begin{array}{l}\text { Strengthening of the Offices of the Comptroller-General (CGR) } \\
\text { and Auditor-General of the Republic }\end{array}$ & 42 & 23 & 19 & 4 \\
\hline 2000 & Honduras $^{\mathrm{d}}$ & $\begin{array}{l}\text { Strengthening and Modernization of the Office } \\
\text { of Administrative Integrity }\end{array}$ & 3 & 2.5 & 0.50 & $\ldots$ \\
\hline 2000 & $\begin{array}{l}\text { Dominican } \\
\text { Republic }\end{array}$ & $\begin{array}{l}\text { Programme for Modernizing the National Congress } \\
\text { and the Office of the Comptroller-General }\end{array}$ & $\begin{array}{l}2.45 \\
(28)^{\mathrm{b}}\end{array}$ & $2.45^{\mathrm{c}}$ & $\ldots$ & 3 \\
\hline 1999 & El Salvador & Modernization and Strengthening of the Accounts Tribunal & 4 & $\ldots$ & $\ldots$ & $\ldots$ \\
\hline 1994 & Uruguay & Modernization of the Accounts Tribunal & 1.50 & 1.41 & 0.09 & $\ldots$ \\
\hline 1993 & Caribbean & Audit Institutions of the Caribbean Countries & 0.81 & 0.60 & 0.21 & $\ldots$ \\
\hline Total & & & 109.26 & 64.91 & & \\
\hline
\end{tabular}

Source: Projects approved or in preparation as of May 2004, www.iadb.org.

a Lending operation at the approval stage.

b Total for the project to modernize parliament and the supreme audit institution.

c Amount allocated to the supreme audit institution. The total is ascribed to the IDB loan because the amount of the local counterpart financing cannot be determined.

d Lending operation at the design phase.

TABLE 3

Latin America: Inter-American Development Bank lending

(Millions of dollars ${ }^{a}$ and percentages)

\begin{tabular}{lccc}
\hline Country & $\begin{array}{c}\text { Supreme audit institution's } \\
\text { annual budget, } \\
\text { millions of dollars }\end{array}$ & \begin{tabular}{c} 
Annual IDB lending \\
\cline { 3 - 3 } Bnilions of dollars
\end{tabular} & $\begin{array}{c}\text { As percentage of supreme audit } \\
\text { institution's annual budget }\end{array}$ \\
\hline Chile (2002) & 242.2 & 1.6 & 0.7 \\
Colombia (2003) & 19.0 & 5.3 & 17.4 \\
Nicaragua (2002) & 54.3 & 1.5 & 10.6 \\
\hline
\end{tabular}

Source: Prepared by the author using data from the reports of supreme audit institutions.

a The fluctuation of the dollar in recent years means that caution is warranted when using it as a referent.

União, tcu) represents a mere $0.08 \%$ of the federal budget (TCU, 2002, p. 38). Third, counterpart financing is often significant, as in Brazil (50\%), Chile (40\%) and Colombia (45\%). These latter two aspects reflect the increasing importance national governments attach to the strengthening of external audit functions. Hence, any assessment of the impact of these innovative projects ought to consider not only their financial size, but also their technical content and institutional focus. 
In broad terms, IDB loans tend to focus on improving the administrative efficiency of supreme audit institutions through strategic and organizational development, human resources management, capability building and training, and improvements in information technology, equipment and infrastructure. They also include provisions for improving relations with civil society. Furthermore, IDB projects have a marked focus on improving legal and financial compliance auditing functions, the core business of supreme audit institutions. They sometimes include provisions for "innovative initiatives", in particular performance auditing, environmental auditing or auditing techniques for regulating agencies of public utilities, such as in Brazil. Furthermore, they usually concentrate their efforts on improving operational auditing of government programmes, especially in the social sectors, rather than enhancing the role of supreme audit institutions in the auditing of the national budget and the certification of public accounts by the legislature. Arguably, this latter core function of supreme audit institutions would be naturally enhanced as a result or "side-effect" of the strengthening of the supreme audit institution as a whole, albeit not automatically.

IDв lending operations only marginally address the functional links between supreme audit institutions and public accounts committees. As table 4 underscores, a series of institutional factors determine the ultimate effectiveness of supreme audit institutions, such as vested powers, supervising authority, nomination and removal procedures, scope of mandate and terms of office. These are areas in which the IDB is reluctant to engage openly. Supreme audit institutions in Latin America are indeed characterized by their great diversity. In Argentina, for example, the Office of the Auditor-General (Auditoría General de la Nación, AGN) is a collegial body that acts as the technical advisory agency to parliament to ensure government accountability and budget oversight; its president is nominated by the main opposition group in parliament. In other countries, such as Chile, Peru and Brazil, supreme audit institutions are nominally independent of both the executive and the legislature. In Brazil, the TCU is a collegial body with a long institutional history that also operates as an administrative court. It concentrates its audit work on compliance auditing of government programmes and agencies. Its main "client" is thus the public administration it audits. In the Andean countries, such as Chile and Peru, supreme audit institutions position themselves as governance institutions, independent of both the executive and the legislature.
Nevertheless, all supreme audit institutions, because of their role as fiscal comptroller, are particularly exposed to political meddling and prone to capture by partisan interests, especially in presidential systems of government. The experience of the Peruvian Comptroller-General's Office (Contraloría General de la República, CGR) between 1993 and 2000 is illustrative. A first strategy for preventing such capture is to strengthen the functional links between the institutions of "horizontal accountability" that are part of the national system of control (O'Donnell, 1998; Schedler, Diamond and Plattner, 1999). Considerations of political economy are thus crucial in explaining the effectiveness of supreme audit institutions, conceived as integral parts of the national systems of fiscal control and anti-corruption.

In particular, the strengthening of the functional links between supreme audit institutions and the other institutions in the national system of fiscal control, in particular the judiciary (administrative and criminal courts) and the legislature (public accounts committees), is key. Whether nominally attached to parliaments or not, supreme audit institutions are functionally linked to them in the "chain of public finance oversight". The case of the support provided by the IDB to Colombia offers an illustration of this, as it reflects an integrated effort to simultaneously strengthen government accountability, public finance integrity, budgetary oversight and law enforcement. In April 2003, the IDB approved a US\$ 14 million loan (as part of a US\$ 20 million programme) to the Office of the AttorneyGeneral (Procuraduría General de la Nación, PGN), the judicial office in charge of overseeing and disciplining public agencies. This programme completes a decadelong financing cycle to modernize oversight and law enforcement agencies in public finance management. In March 2000 a US\$ 23 million loan was granted (as part of a US\$ 42 million programme) to the offices of the Comptroller-General (Contraloría General de la República, CGR) and Auditor-General (Auditoría General de la República, AGR), and in December 1995 a US\$ 9.5 million loan (part of a US\$ 15.7 million programme) went to modernize the administration of justice and the Public Prosecutor's Office (Fiscalía General de la Nación, FGN). All three loans had significant counterpart financing (US\$ 77.7 million in total), reflecting the commitment of Colombia to these programmes.

Supreme audit institutions provide critical advisory services to parliaments, directly or indirectly, in the exercise of their accountability functions. However, relations between supreme audit institutions 


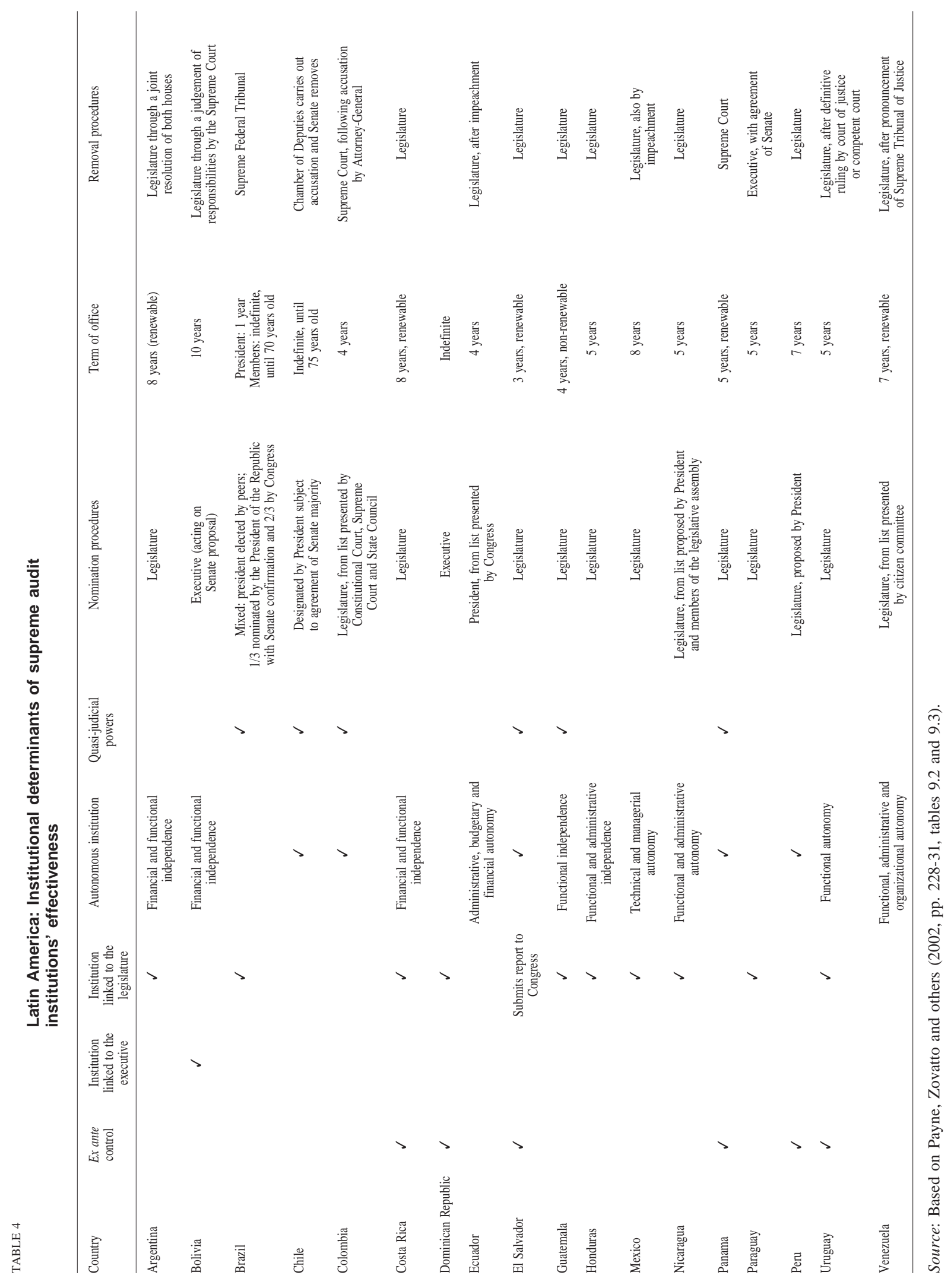


and parliamentary budget and public accounts committees are deficient, often characterized by polite indifference. Loans to supreme audit institutions tend to overlook the dysfunctional linkages between these bodies and parliaments. While IDB lending to national parliaments focuses on enhancing their role in budget policy-making, support to supreme audit institutions tends to neglect their role in budget oversight and auditing. Only in a few countries, such as the Dominican Republic in 2000 and El Salvador in 1999, has the IDB addressed the relationship between supreme audit institutions and parliaments. In these two instances, loans were made simultaneously to both institutions; in the case of the Dominican Republic, they were merged into a single loan.

IDB lending operations tend to avoid confronting the broader governance context in which supreme audit institutions operate and the incentives conditioning public finance accountability. They seldom seek to enhance the political independence and financial autonomy of these institutions in an active and purposeful manner. Issues such as the criteria guiding the nomination and removal of auditors-general and the length of their term in office, and the procedures regulating recruitment, promotion and dismissal of professional staff, are nevertheless critical determinants of the effective independence of supreme audit institutions. Credible appointment criteria and stability of tenure determine the extent to which auditorsgeneral are likely to behave independently. Predictable financial resources are also a necessary (albeit not sufficient) condition for institutionalizing supreme audit institutions and insulating them from political meddling (INTOSAI, 2001).

Politicization of the auditor-general's appointment procedure and that of the supreme audit institution's staff is a major hindrance to the effective independence of the institution. When the government controls a majority in parliament, in either parliamentary or presidential systems, nominations often reflect political bargains. Furthermore, short terms of office that coincide with that of the president tend to reduce the incentives for auditors-general to exercise any political independence they may have. Ultimately, these individual incentives motivate the institutional behaviour of supreme audit institutions. In Argentina, for example, the constitution and the law on financial administration stipulate that auditors-general are appointed for an eight-year renewable term. However, in an effort to increase the independence of the AGN, an amendment to the constitution in 1994 established that the president of the AGN was to be chosen from the main opposition party. As a result, presidents of the AGN have changed as government majorities have. Furthermore, the politicization of the civil service has entailed high rates of staff turnover and thus has not allowed the consolidation of technical expertise and an "esprit de corps" within the supreme audit institution. A highly capable and respected civil service, with stability of tenure and reasonable career prospects within the institution, is crucial for consolidating a professional approach to the external auditing of government finances. ${ }^{12}$

In general, strengthening technical capacity per se does not necessarily improve the effectiveness of supreme audit institutions, nor has it prevented them from being captured, as in the case of Nicaragua. Yet, securing the effective independence of these institutions is a critical determinant of their ultimate ability to hold government accountable, as was underscored by the 1977 Lima declaration of principle of the International Organization of Supreme Audit Institutions (INTOSAI) and, more recently, the final report of the INTOSAI task force on independent government auditing (INTOSAI, 2001). It is widely recognized that an inherent weakness of the State in developing countries resides in the frailty of the institutional mechanisms of "horizontal accountability" anchored in those State institutions whose function is to control government and restrain the State (Mainwaring and Welna, 2003).

\footnotetext{
${ }^{12}$ Moreover, IDB lending operations have tended to concentrate their efforts at the national or federal level. The mechanisms for internal and external auditing of government finances are particularly weak at the local level, often being captured by local elites. The IDB is only just starting to support subnational supreme audit institutions in federal systems and to cooperate with the deconcentration of such institutions in unitary States.
} 


\section{IV}

\section{The politics of public finance accountability}

A decade after the emergence of governance to the forefront of the development agenda, new approaches to governance reform and institutional development are warranted. These require in particular a narrowing of the gap between economic and political facets of multilateral development finance. The assessment of the IDB approach to the modernization of budget oversight institutions is particularly instructive in that regard, as the IDB is the most political of the multilateral development banks.

The impact of IDB lending to parliaments and supreme audit institutions is still difficult to decipher. As Kaufmann (2003, p. 3) notes, "we need to take into consideration that this effort has taken place against the backdrop of a relatively undeveloped state of the art in the complex and multidisciplinary field of governance and anticorruption". There are a number of difficulties in evaluating results. First, it is necessary to define indicators of impact for this new type of projects that deliberately set out to strengthen institutions. A second and even more critical challenge is to identify indicators that can measure the performance and ultimate impact of the institutions of control themselves. A third challenge is to decide how the politics of public finance accountability can best be addressed, and to what degree. When all this is done, the number and variety of explanatory variables expands considerably. Acknowledging the importance of the politics of budgeting and the political economy of public finance accountability is certainly a step forward.

Nevertheless, IDB lending to national parliaments and supreme audit institutions displays a reluctance to confront dysfunctions in the political economy of fiscal control and the politics of financial accountability. The bulk of IDB financing to budget oversight institutions is directed towards hardware investments, such as infrastructure development, information technology and human resources management. In a more recent past, IDB support has also been directed at reforming the procedures and strengthening the structures framing the parliamentary budget process, such as budget and finance committees, legislative research capacities and legislative budget offices. Only a handful of Latin
American parliaments such as those of Brazil, Chile, Peru, and Venezuela do possess such independent research and advisory capabilities. The IDB increasingly advocates strengthening these where they exist, and creating them where they do not.

The IFIs justify their apolitical approach by arguing that technical improvements can, over time, contribute to improving governance, without being diluted in the intricacies of politics. Framing governance as a technical question has indeed allowed them to justify their involvement in governance issues, while remaining within the boundaries of their respective mandates. There are limits to this technocratic consensus, however. This functionalist approach gives the illusion that technical solutions can solve political problems. Institutional reforms in public budgeting are inherently political (Shepsle, 1999; Wildavsky, 1964 and 1992). While usually couched in the language of efficiency, public finance reform affects power relations, as the budget is a key arena for political bargaining. Decisions as to who controls the budget process and how budgetary allocations are made are intrinsically political. As a consequence, trying to separate the economic and the political facets of public budgeting is, to a large extent, artificial. As Kaufmann (2003, p. 33) underscores, "a proper understanding of the political forces affecting policymaking and, related, the set of required institutional incentives for progress" is necessary to understand the dynamics of budgetary reform.

The IDB (2003, p. 9) does recognize that "projects that are limited to changing instrumental elements or simply strengthen technical organizational capacities, without altering the structure of incentives that affect the political will to apply them are likely in general to have a negligible impact. Thus institutional changes that condition the effectiveness of instrumental and organizational reforms need to be addressed at the same time [...] It does little good to establish a financial management system without the development of a budgetary authority with the professional independence, power, and capacity to enforce it." Reform efforts fail not only because they are incomplete, but also because they are often designed 
to solve technical shortcomings when the problem lies in the institutional framework.

A broader understanding of the governance of the budget process is thus warranted. Supreme audit institutions and public accounts committees occupy key positions in the architecture of public finance management and fiscal control (Wehner, 2003; Petri 1998). The quality of parliament's oversight of government finances depends critically on credible information and independent budget analysis being provided by supreme audit institutions in a timely manner. At the same time, the effectiveness and ultimate impact of supreme audit institutions largely depend on the extent to which parliaments act upon the recommendations of their audit reports. Thus, the quality of the functional linkage and institutional relationships between parliamentary public accounts committees and supreme audit institutions is key (sIgma, 2002). Again, the ability of supreme audit institutions to fulfil their mandate depends on their effective independence from government and, at the same time, the cooperation they receive from government agencies.

Relations between supreme audit institutions and public accounts committees are decisive for the enforcement of government accountability. Institutional arrangements and incentive structures largely explain the ultimate effectiveness of both. First, the reports and recommendations of supreme audit institutions are largely ineffective if they are not acted on by other institutions that are part of the system of control, in particular the public administration itself (administrative accountability), the judiciary (criminal accountability) and parliament (political accountability). Thus, their effectiveness is conditional on the cooperation of other State institutions. Furthermore, in many cases, especially in presidential systems, the consent of a qualified majority of members of parliament (often two thirds), including the ruling party, is required to nominate auditors-general. The political bargains that are struck often undermine the political independence of the chosen candidate.

Second, the willingness of public accounts committees to exercise their powers and hold government to account is also determined by broader governance factors. These committees are a reflection of legislative politics and the nature of executivelegislative relations (Morgenstern and Nacif, 2002). Indeed, their composition reflects that of parliament itself and, as a result, the ruling party often controls them. By contrast with parliamentary systems, where they are presided over by a representative of the opposition, in Latin America the chairmanship of budget and public accounts committees traditionally goes to a member of the ruling party. Indeed, it could be argued that the effectiveness of the mechanisms of horizontal accountability within the State ultimately depends on the effectiveness of the mechanisms of vertical accountability, in particular electoral rules and party structures.

The behaviour of members of parliament is itself shaped by the incentives to which they respond. Executive-legislative relations are necessarily intermediated by political party systems and electoral rules, as there is a possibility of control being diluted when the ruling party or coalition holds a majority position in parliament. Recent research on the politics of budgeting in Brazil ${ }^{13}$ shows that participation by the legislative branch in the budget process can only be understood when the political parties and electoral rules are taken into account. As the executive dominates the budget process and controls budget execution, the way parties participate in this process depends on their relations with the executive (Pereira and Mueller, 2002). Indeed, in presidential systems marked by the fusion of executive and legislative majorities, systems for enforcing government accountability tend to be inoperative.

There thus exists unexplored potential in the support provided by multilateral development banks to Latin America's supreme audit institutions and public accounts committees. The second stage of multilateral support to budget oversight institutions should thus seek to strengthen the political independence and financial autonomy of supreme audit institutions, and promote more effective links between these and parliamentary public accounts committees. Analysis of IDB loans often reveals that such linkages are absent from the design of these interventions. In general, IDB lending operations tend to be designed as selfcontained interventions, which has the advantage of protecting them from unwarranted external interference, but which also has the disadvantage of inhibiting synergies between them.

Furthermore, the IFIs should also endeavour to design integrated initiatives addressing the entire budgetary cycle and the governance of the budget process as a whole. This would require linking efforts

${ }^{13}$ See Mainwaring and Welna (2003), Morgenstern and Manzetti (2003) and Figueiredo (2001 and 2003). 
to coordinate projects intended to modernize public financial management information systems within the executive with those aimed at enhancing the contribution of external audit agencies and legislative committees. This would also mean integrating efforts to improve public finance management and accountability more tidily with those aimed at consolidating the rule of law, reforming civil services, strengthening legislatures and combating corruption.

More fundamentally, multilateral lending operations aimed at strengthening budget oversight institutions need to factor in and engage with structural power dynamics. As Messick (2002, p. 1) underscores, "success requires changing the incentives facing public officials [...] Constitutional structure and party cohesion are key determinants of a legislature's independence." Increasing technical capacity and enhancing analytical capabilities by building up legislative research services or improving investigation techniques in audit institutions are likely to remain ineffectual as long as there is not enough political space for them to be exercised effectively. Technical improvements are likely to be emasculated by adverse political dynamics and governance constraints. The key question is whether endowing oversight institutions with more technical capacity can strengthen them, or whether increased independence and assertiveness would lead these institutions to create and utilize more technical capacity. The IDB tends to rely on the first approach, focusing on building up the technical capacity of oversight institutions. However, there are reasons to believe that the latter might be an efficacious complementary strategy, and it is now within the purview of the new IDB strategy for reforming the State and modernizing government adopted in $2003 .{ }^{14}$
AfDB (African Development Bank) (2000): Good Governance Policy, Abidjan, AfDB Operational Strategy.

Ahrens, J. (2001): Governance, conditionality and transformation in post-socialist countries, in H. Hoen (ed.), Good Governance in Central and Eastern Europe, Cheltenham, Edward Elgar.

AsDB (Asian Development Bank) (1995): Governance: Sound Development Management, Board Paper, Manila, August. (1999): Governance in Asia: from crisis to opportunity, Annual Report 1998, Manila.

Biebessheimer, C. and M. Payne (2001): IADB Experience in Justice Reform: Lessons Learned and Elements for Policy Formulation, IADB Technical Paper, Washington, D.C.

Brobäck, U. and S. Sjölander (2002): Programme Support and Public Finance Management: A New Role for Bilateral Donors in Poverty Strategy Work, Sida Studies, No. 6, Stockholm.

Burki, S.J., G. Perry and others (1998): Beyond the Washington Consensus. Institutions Matter, Washington, D.C., World Bank.

Carbonell, M. (2002): Los conflictos entre el poder legislativo y el poder ejecutivo en México, Contribuciones, No. 3, Buenos Aires, Centro Interdisciplinario de Estudios sobre el Desarrollo Latinoamericano (CIEDLA).

DFID (Department for International Development) (2001): Understanding and Reforming Public Expenditure Management, London.

(2002): Managing Fiduciary Risk when Providing Direct Budget Support, London.

Diamond, J. (2002): The Role of Internal Audit in Government Financial Management: An International Perspective, IMF Working Paper, WP/02/94, Washington, D.C., Fiscal Affairs Department, International Monetary Fund, May.

Dorotinsky, W. and Y. Matsuda (2002): Reforma de la gestión financiera en América Latina: una perspectiva institucional, Reforma y democracia, No. 23, Caracas, Latin American Centre for Development Administration (CLAD).

Drake, P. (1989): Money Doctor in the Andes: the Kemmerer Missions, 1923-1933, Durham, Duke University Press.
Eaton, K. (2002): Fiscal policy making in the Argentine legislature, in S. Morgenstern and B. Nacif (eds.) (2002): Legislative Politics in Latin America, Cambridge, Cambridge University Press.

EBRD (European Bank for Reconstruction and Development) (1992): Political Aspects of the Mandate of the EBRD, London.

Figueiredo, A. (2001): Instituições e política no controle do executivo, Dados, vol. 44, No. 4, Rio de Janeiro, Instituto Universitário de Pesquisas do Rio de Janeiro.

(2003): The role of Congress as an agency of horizontal accountability: lessons from the Brazilian experience, in $\mathrm{S}$. Mainwaring and C. Welna (eds.) (2003): Democratic Accountability in Latin America, Oxford, Oxford University Press.

Fuhr, H. and P. Krause (2003): Overview of Core Public Sector Reform Projects 1982-2002, Washington, D.C., World Bank.

Haggard, S. and M.D. McCubbins (eds.) (2001): Presidents, Parliaments, and Policy, Cambridge, Cambridge University Press.

IDB (Inter-American Development Bank) (1996): Frame of Reference for Bank Action in Programs for Modernization of the State and Strengthening Civil Society, IADB GN-1883-5, Washington, D.C. (2003): Modernization of the State: Strategy Document, BID 7/03, GN-2235-1, Washington, D.C.

IMF (International Monetary Fund) (1997): Good Governance: The IMF's Role, Washington, D.C.

(2001): Review of the Fund's Experience in Governance Issues, Washington, D.C.

INTOSAI (International Organization of Supreme Audit Institutions) (2001): Independence of Supreme Audit Institutions: Final Task Force Report, Vienna, General Secretariat.

Jones, M. (2001): Political institutions and public policy in Argentina: an overview of the formation and execution of the national budget, in S. Haggard and M.D. McCubbins (eds.), Presidents, Parliaments, and Policy, Cambridge, Cambridge University Press.

\footnotetext{
14 See IDB (2003).
} 
Kaufmann, D. (2003): Rethinking Governance: Empirical Lessons Challenge Orthodoxy, Discussion Draft, Washington, D.C., World Bank, March.

Krafchik, W. and J. Wehner (1998): The role of parliaments in the budget process, South African Journal of Economics, vol. 66, No. 4, Lynwood Ridge, Economic Society of South Africa (ESSA).

Krueger, A. (ed.) (2000): Economic Policy Reform: The Second Stage, Chicago, University of Chicago Press.

Kuczynski, P. and J. Williamson (eds.) (2003): After the Washington Consensus: Restarting Growth and Reform in Latin America, Washington, D.C., Institute for International Economics (IIE).

Llanos, P. (2002): Las entidades fiscalizadoras superiores y la cooperación internacional, document presented at the EUROSAI-OLACEFS II Euro-American Meeting of Supreme Audit Institutions (Cartagena de Indias, Colombia, 11 July).

Mainwaring, S. and C. Welna (eds.) (2003): Democratic Accountability in Latin America, Oxford, Oxford University Press.

Manning, N. and R. Stepenhurst (2002): Strengthening Oversight by Legislatures, PREM Note, No. 74, Washington, D.C., World Bank, October.

Messick, R. (2002): Strengthening Legislatures: Implications from Industrial Countries, PREM Note, No. 63, Washington, D.C., World Bank

Morgenstern, S. and L. Manzetti (2003): Legislative oversight: interests and institutions in the United States and Argentina, in S. Mainwaring and C. Welna (eds.) (2003): Democratic Accountability in Latin America, Oxford, Oxford University Press.

Morgenstern, S. and B. Nacif (eds.) (2002): Legislative Politics in Latin America, Cambridge, Cambridge University Press

O'Donnell, G. (1998): Horizontal accountability in new democracies, Journal of Democracy, vol. 9, No. 3, Baltimore, Maryland, The Johns Hopkins University Press.

OECD (Organisation for Economic Co-operation and Development) (1998): The Role of the Legislature, Paris.

(2001a): OECD Best Practices for Budget Transparency, OECD PUMA/SBO(2000)6/FINAL, Paris.

(2001b): Budget: Towards a New Role for the Legislature, Paris.

Payne, M., D. Zovatto and others (2002): Democracies in Development: Politics and Reform in Latin America, Washington, D.C., Inter-American Development Bank (IDB).

PEFA (Public Expenditure and Financial Accountability) (2003): Assessing Public Expenditure, Procurement and Financial Accountability: A Review of the Diagnostic Instruments, Washington, D.C.

Pereira, C. and B. Mueller (2002): Comportamento estratégico em presidencialismo de coalizão: as relações entre executivo e legislativo na elaboração do orçamento brasileiro, Dados, vol. 45, No. 2, Rio de Janeiro, Instituto Universitário de Pesquisas do Rio de Janeiro.

Petri, H. (1998): Budget and Control: Reforming the Public Sector in Latin America, Washington, D.C., Inter-American Development Bank (IDB).

Rojas, E. and H. Zavarce (2004): Instituciones para la coordinación de la política monetaria y fiscal: un enfoque transaccional para el caso venezolano, document presented at the XVI Regional Seminar on Fiscal Policy (ECLAC, Santiago, Chile, 26-29 January 2004).

Rubio Llorente, F. (1993): La forma del poder, Madrid, Centro de Estudios Constitucionales.

Samuels, D. (2002): Progressive ambition, federalism and porkbarreling in Brazil, in S. Morgenstern and B. Nacif (eds.) (2002): Legislative Politics in Latin America, Cambridge, Cambridge University Press.

Santiso, C. (n/d): The Governance of the Budget in Emerging Economies: Institutions of Accountability, Oversight and Anticorruption in Public Finance, unpublished.
(2000): Towards democratic governance: the contribution of the multilateral development banks in Latin America, in P. Burnell (ed.), Democracy Assistance: International Cooperation for Democratization, London, Frank Cass.

(2001a): Democratic governance and second generation economic reforms in Latin America, Instituciones y desarrollo, 8-9, Barcelona, Instituto Interamericano de Gobernabilidad, May.

(2001b): Insulated economic policy and democratic consolidation: the paradox of second generation reforms in Argentina during the 1990s, Contribuciones, year 18, No. 4(72), Buenos Aires, Centro Interdisciplinario de Estudios sobre el Desarrollo Latinoamericano (CIEDLA), December.

(2001c): Good governance and aid effectiveness: The World Bank and conditionality, Georgetown Public Policy Review, vol. 7, No. 1, Washington, D.C., Georgetown University.

(2003a): Another lost decade? The future of reform in Latin America, Public Administration and Development, vol. 23, No. 4, New York, John Wiley and Sons.

(2003b): The elusive search for the rule of law: promoting judicial reform in Latin America, Brazilian Journal of Political Economy, vol. 23, No. 3, São Paulo.

(2004a): Re-forming the State: governance institutions and the credibility of economic policymaking, International Public Management Journal, vol. 7, No. 3, International Public Management Network.

(2004b): Legislative Budget Oversight and Public Finance Accountability in Presidential Systems: Governance of the Budget in Peru, document prepared for the XVI Regional Seminar on Fiscal Policy (EClaC, Santiago, Chile, 26-29 January 2004).

(2004c): The contentious Washington Consensus: reforming the reforms in emerging markets, Review of International Political Economy, vol. 11, No. 4, London, Routledge.

(2004d): The political economy of governance and conditionality in multilateral development finance, International Public Management Journal, vol. 7, No. 1, International Public Management Network.

Schedler, A., L. Diamond and M. Plattner (eds.) (1999): The SelfRestraining State: Power and Accountability in New Democracies, Boulder, Colorado, Lynne Rienner.

Shepsle, K. (1999): The political economy of state reform: political to the core, Brazilian Journal of Political Economy, vol. 19, No. 3, São Paulo.

SIGMA (Support for Improvement in Governance and Management) (2002): Relations Between Supreme Audit Institutions and Parliamentary Committees, SIGMA Paper, No. 33, CCNM/GOV/ SIGMA(2002)1, Paris.

TCU (Tribunal de Contas da União) (2002): Relátorio das actividades do TCU, 3 Trimestre de 2002, Brasilia, D.F.

Wehner, J. (2002): Best Practices in Public Accounts Committees, unpublished.

(2003): Back from the Sidelines? Redefining the Contribution of Legislatures to the Budget Cycle, unpublished.

Weldon, J. (2002): Legislative delegation and the budget process in Mexico, in S. Morgenstern and B. Nacif (eds.) (2002): Legislative Politics in Latin America, Cambridge, Cambridge University Press.

Wildavsky, A. (1964): The Politics of the Budgetary Process, Boston, Little, Brown.

(1992): Political implications of budget reform: a retrospective, Public Administration Review, No. 52, Oxford, Blackwell Publishing.

World Bank (1992): Governance and Development, Washington, D.C.

(1997): World Development Report 1997: The State in a Changing World, New York, Oxford University Press.

(2000): Reforming Public Institutions and Strengthening Governance: A World Bank Strategy, Washington, D.C., Public Sector Group. 